Ellen Webb, Sheila Bushkin-Bedient*, Amanda Cheng, Christopher D. Kassotis, Victoria Balise and Susan C. Nagel*

\title{
Developmental and reproductive effects of chemicals associated with unconventional oil and natural gas operations
}

\begin{abstract}
Unconventional oil and gas (UOG) operations have the potential to increase air and water pollution in communities located near UOG operations. Every stage of UOG operation from well construction to extraction, operations, transportation, and distribution can lead to air and water contamination. Hundreds of chemicals are associated with the process of unconventional oil and natural gas production. In this work, we review the scientific literature providing evidence that adult and early life exposure to chemicals associated with UOG operations can result in adverse reproductive health and developmental effects in humans. Volatile organic compounds (VOCs) [including benzene, toluene, ethyl benzene, and xylene (BTEX) and formaldehyde] and heavy metals (including arsenic, cadmium and lead) are just a few of the known contributors to reduced air and water quality that pose a threat to human developmental and reproductive health. The developing fetus is particularly sensitive to environmental factors, which include air and water pollution. Research shows that there are critical windows of vulnerability during prenatal and early postnatal development, during which chemical exposures can cause potentially permanent damage to the growing embryo and fetus. Many of the air and water pollutants found near UOG operation sites are recognized as being developmental and reproductive toxicants; therefore there is a compelling need to increase our knowledge of the potential health consequences for adults, infants, and children from these chemicals through rapid and thorough health research investigation.
\end{abstract}

\footnotetext{
*Corresponding authors: Sheila Bushkin-Bedient, Institute for Health and the Environment 5 University Place Suite A 217, Rensselaer, New York, USA, E-mail: sbushkin@nycap.rr.com; and Susan C. Nagel: University of Missouri - Obstetrics, Gynecology and Women's Health Missouri, Illinois, USA,

E-mail:nagels@health.missouri.edu

Ellen Webb: Center for Environmental Health, New York, USA Amanda Cheng: Center for Environmental Health, New York, USA Christopher D. Kassotis and Victoria Balise: University of Missouri Biological Sciences, Columbia, Missouri, USA
}

Keywords: birth defects; impaired fetal growth; infertility; low birth weight; maternal health; spontaneous abortion; unconventional oil and natural gas extraction (UOG) miscarriage.

DOI 10.1515/reveh-2014-0057

Received August 1, 2014; accepted November 5, 2014

\section{Chemicals and wastewater associated with unconventional oil and natural gas (UOG) operations}

The rapid rise in unconventional oil and natural gas (UOG) operations that combine directional drilling and hydraulic fracturing (fracking) increases the opportunity for air and water pollution from these processes, with over 15 million Americans living within one mile of UOG operations. UOG operations involve the injection of millions of gallons of water and thousands of gallons of chemicals into the ground under high pressure to liberate oil and gas. More than 750 chemicals are added throughout the UOG process (1). A subset of chemicals is typically used for individual well pads in order to maximize production based on geology and other factors. These chemicals are added for a number of reasons including the following: increasing the viscosity to keep proppants suspended, preventing corrosion and build-up within pipes, helping to dissolve chemicals into fracturing fluids that facilitate the formation of fractures underground, preserving the viability of the fluids during storage, and preventing bacterial growth in fracturing fluids and pipes (1-3). Some fluids return to the surface immediately and some return to the surface over the life of a producing well; these contain the hydraulic fracturing chemicals and also naturally occurring compounds such as radioactive materials, salts, and heavy metals that are liberated from the shale layer (2, 4-7). Industry reports using approximately 
13 known or suspected carcinogens (including benzene and acrylamide), known developmental neurotoxicants, and many volatile organic compounds (VOCs) including the BTEX (benzene, toluene, ethylbenzene, and xylene) chemicals, which have numerous associated adverse health outcomes in humans (1).

UOG operations release large amounts of reproductive, immunological, and neurological toxicants, carcinogens as well as endocrine disrupting chemicals (EDCs) into the environment that may negatively affect human health (8). The chemicals used in or produced by UOG have been linked to negative health effects, including adverse reproductive and developmental outcomes in men, women, infants and children. This article will review evidence that adult and early life exposure to chemicals associated with UOG operations can lead to adverse reproductive and developmental health effects in humans, including infertility, miscarriage, impaired fetal growth, low birth weight, preterm birth, and birth defects (9-14). Many of these same reproductive health impacts have also been observed in companion and farm animals living in intensively drilled areas in the United States (15).

\section{Endocrine disrupting chemicals (EDCs)}

Hormones are essential for normal health and development. The Endocrine Society defines EDCs as "Any chemical or mixture of chemicals that interferes with any aspect of hormone action" (16). EDCs can interfere with hormone action in a number of ways, but the two most common are through binding to endogenous hormone receptors or altering endogenous hormone concentrations. EDCs can bind to endogenous hormone receptors and activate or repress the normal response; these can also modify endogenous hormone concentrations by altering hormone synthesis or metabolism and clearance. EDCs are often small lipophilic molecules that can dissolve in the plasma membrane and bind to intracellular receptors. Hence, common targets are ligand activated transcription factors in the nuclear receptor superfamily, including estrogen, androgen, glucocorticoid, progesterone, and thyroid hormone receptors. Hormones work at very low concentrations, for example, estrogens stimulate cell proliferation in the part per trillion range; moreover, while typically less potent, EDCs are often present at much higher concentrations than endogenous hormones (17). EDCs can also stimulate nonmonotonic dose responses, that is, effects seen at high doses do not necessarily predict the quantitative and/or qualitative effects seen at low doses (18).
A potential source of exposure to EDCs is through their use in UOG operations. More than 130 fracturing chemicals have been identified as known or potential EDCs, and many others have yet to be assessed due to lack of Chemical Abstract Service numbers and/or proprietary information concerns $(1,8,19)$. Kassotis et al. previously assessed the EDC activities of 24 fracturing chemicals on five hormone receptors, reporting antagonist activities for the majority of the chemicals examined $(19,20)$, the first report of direct receptor activity for many of them (21-26). Additional work found that surface and ground water from fracturing fluid spill sites in Garfield County, Colorado, exhibited higher EDC activities than samples collected outside the active drilling region (19). Adverse reproductive health outcomes associated with EDC exposures are well documented, with reported effects on reproductive organs, body weight, puberty, fertility, and reproductive cancer incidence (27-31).

\section{Wastewater associated with UOG operations}

After the drilling and fracturing phase, a portion of the fracturing fluids immediately return to the surface as flowback water. Large volumes of water, which originate from within the shale layer, later comes to the surface throughout the life of the well and is termed "produced water". Residual fracturing chemicals can continue to emerge with produced water in addition to other compounds that are naturally occurring in the bedrock. Some components of fracturing chemicals remain underground and have an unknown fate. After the desired oil and natural gas components have been separated, the remaining flowback and produced water are considered "wastewater", which now contains industrial fracking chemicals plus naturally occurring substances from the shale or coal bed layer. These include heavy metals, salts, minerals and radioactive substances, which escape from their natural underground location along with the oil and natural gas. Recycling of UOG fluids is often employed, however, this practice is limited in frequency because chemicals can become concentrated in these fluids. Ultimately, a large amount of waste is generated. Traditional wastewater treatment does not adequately remove all of these chemicals.

Currently, there are many strategies to dispose of the millions of gallons of wastewater generated by UOG operations, but none are without risks of environmental contamination. UOG wastewater is disposed of in injection disposal wells, landfills, evaporation pits, municipal wastewater treatment plants, direct discharge into 
surface water and other miscellaneous uses like spraying onto roads to reduce dust or melt ice on roads (32). Most of these practices can either directly or indirectly aerosolize chemicals or contaminate surface and ground water. The current practice of injecting large volumes of wastewater, under high hydraulic pressure, has been shown to cause increased seismic activity and earthquakes $(33,34)$. Although the separation of some naturally occurring radioactive elements in fracturing fluids is known to occur at wastewater treatment centers through the co-precipitation of radium with barium and strontium sulfate, the radium still persists in the environment either through incomplete removal from wastewater or as solid waste produced via co-precipitation $(35,36)$. Thus, radioactive elements like radium (a known carcinogen) will persist in wastewater, in river sediments, and in waste facilities where precipitate and sludge are disposed. Even when disposed of in landfills and other waste facilities, eventual migration or release of leachate into surface and ground water can still occur (37), thus creating another potential mechanism for environmental contamination with these compounds $(35,36)$.

\section{Potential routes of exposure to UOG chemicals}

Human and animal exposure to UOG chemicals can occur through oral routes like eating, through drinking and dermal routes like cleaning and bathing, and via inhalation of airborne contaminants emitted throughout all stages of UOG lifecycle including production $(38,39)$.

\section{Water}

UOG operations can contaminate both surface and ground water $(5,7,35,38,40-47)$. Routes of contamination include spills during transport to and from well pads, injection of fluids, failure of cement well casings, and from improper treatment and disposal of wastewater $(38,41,48-50)$. Spills are commonly reported, occurring in approximately $1 \%$ of all Colorado wells in 2013 (51, 52), with subsequent leaching into ground water occurring at some of these locations $(45,53)$. Gas and heavy metal concentrations increase in drinking water with proximity to natural gas wells $(7,42$, 43, 54). In fact, a recent work has suggested that faulty well casings may be the primary source of this contamination (55). The transportation of chemicals and wastewater to and from well pads also contributes to contamination through traffic accidents and equipment failures of tanker trucks $(56,57)$. Even when wastewater is treated, it is commonly sent to facilities not designed to remove many of the anthropogenic and naturally occurring compounds present $(56,58-60)$, resulting in elevated downstream concentrations of radium, barium, strontium, benzene, and other compounds $(35,47)$. Importantly, surface water accounts for two-thirds of all drinking water use (61).

\section{Air}

Oil and natural gas production processes contribute numerous contaminants into the air, resulting in elevated concentrations of hydrocarbons, methane, ozone, nitrogen oxides $\left(\mathrm{NO}_{\mathrm{x}}\right)$, and VOCs like BTEX, alkenes, alkanes, aromatic compounds, and aldehydes (39, 62-75). VOCs are carbon-based chemicals that easily evaporate at ambient temperatures due to high vapor pressure. Many of these can become dangerous if inhaled in large amounts from the ambient air. BTEX chemicals and formaldehyde are just a few of the many VOCs associated with the various stages of UOG operations. Diesel truck exhaust, emissions from drilling rigs and pumps to obtain chemicals released from natural gas wells also produce VOCs (76). The release of VOCs from some of these sources can include BTEX, and can occur during venting, flaring, production, and from leaks due to faulty casings (77). A cluster of wells located in a small area can lead to the significant accumulation of VOCs in the surrounding air (76). Formaldehyde was found in air samples in a drilling dense area in Garfield County in rural western Colorado and near residential sites (78); it can also be produced during the combustion of natural gas (79). Formaldehyde and acetaldehyde can also form from the chemical reaction caused by sunlight interacting with $\mathrm{NO}_{\mathrm{x}}$ and VOCs (78). Air emissions around drill sites and compressor stations have been reported to have elevated concentrations of benzene, formaldehyde, hexane, and hydrogen sulfide. In some cases, their concentrations significantly exceeded the Minimal Risk Level of Hazardous Substances (MRL) of the Agency for Toxic Substances and Disease Registry (ATSDR) and were associated with health impacts on residents (80). Table 1 shows a selected list of hazardous substances on the ATSDR MRL list, which coincide with some of the most common air pollutants.

Ground level ozone is a health concern associated with UOG operations. Ground level ozone is a pollutant that forms when $\mathrm{NO}_{\mathrm{x}}$ react with VOCs in the presence of sunlight (81). Release of $\mathrm{NO}_{\mathrm{x}}$ and VOCs begins with the use of diesel powered equipment during site preparation and emissions from diesel powered equipment, and 
Table 1 Selected chemicals from ATSDR Minimal Risk Levels for Hazardous Substances.

\begin{tabular}{|c|c|c|c|c|}
\hline Chemical & Exposure Route & $A^{a} / I^{b} / C^{c}$ & MRL & Toxic endpoint \\
\hline \multirow[t]{5}{*}{ Benzene } & Inhalational & $A$ & $0.009 \mathrm{ppm}^{\mathrm{d}}$ & Immuno \\
\hline & Inhalational & 1 & $0.006 \mathrm{ppm}$ & Immuno \\
\hline & Inhalational & $\mathrm{C}$ & $0.003 \mathrm{ppm}$ & Immuno \\
\hline & Oral & $\mathrm{C}$ & $0.0005 \mathrm{mg} / \mathrm{kg} / \mathrm{day}$ & Immuno \\
\hline & & & & Immuno \\
\hline \multirow[t]{5}{*}{ Formaldehyde } & Inhalational & $A$ & $0.04 \mathrm{ppm}$ & Resp \\
\hline & Inhalational & I & $0.03 \mathrm{ppm}$ & Resp \\
\hline & Inhalational & C & $0.008 \mathrm{ppm}$ & Resp \\
\hline & Oral & 1 & $0.3 \mathrm{mg} / \mathrm{kg} / \mathrm{day}$ & Gastro \\
\hline & Oral & C & $0.2 \mathrm{mg} / \mathrm{kg} / \mathrm{day}$ & Gastro \\
\hline Hexane & Inhalational & C & $0.6 \mathrm{ppm}$ & Neuro \\
\hline \multirow[t]{2}{*}{ Hydrogen sulfide } & Inhalational & A & 0.07 ppm & Resp \\
\hline & Inhalational & I & $0.02 \mathrm{ppm}$ & Resp \\
\hline \multirow[t]{4}{*}{ Ethylbenzene } & Inhalational & $A$ & $5 \mathrm{ppm}$ & Neuro \\
\hline & Inhalational & 1 & $2 \mathrm{ppm}$ & Neuro \\
\hline & Inhalational & C & $0.06 \mathrm{ppm}$ & Renal \\
\hline & Oral & 1 & $0.4 \mathrm{mg} / \mathrm{kg} / \mathrm{day}$ & Hepatic \\
\hline \multirow[t]{4}{*}{ Toluene } & Inhalational & A & $1 \mathrm{ppm}$ & Neuro \\
\hline & Inhalational & $\mathrm{C}$ & $0.08 \mathrm{ppm}$ & Neuro \\
\hline & Oral & A & $0.8 \mathrm{mg} / \mathrm{kg} / \mathrm{day}$ & Neuro \\
\hline & Oral & I & 0.02 mg.kg.day & Neuro \\
\hline \multirow[t]{6}{*}{ Xylenes (mixed) } & Inhalational & $A$ & $2 \mathrm{ppm}$ & Neuro \\
\hline & Inhalational & 1 & 0.6 ppm & Neuro \\
\hline & Inhalational & $\mathrm{C}$ & $0.05 \mathrm{ppm}$ & Neuro \\
\hline & Oral & A & $1 \mathrm{mg} / \mathrm{kg} /$ day & Neuro \\
\hline & Oral & 1 & $0.4 \mathrm{mg} / \mathrm{kg} / \mathrm{day}$ & Neuro \\
\hline & Oral & C & $0.2 \mathrm{mg} / \mathrm{kg} / \mathrm{day}$ & Neuro \\
\hline
\end{tabular}

${ }^{\mathrm{a}} \mathrm{A}$, Acute; ${ }^{\mathrm{b}}$, Intermediate; ${ }^{\mathrm{C} C}$, Chronic; ${ }^{\mathrm{d}} \mathrm{ppm}$, parts per million. These data were last updated on July 12, 2013.

Source: Agency for Toxic Substance and Disease Registry. http://www.atsdr.cdc.gov/mrls/mrllist.asp.

continues through the processes of drilling and extraction using hydraulic fracturing when millions of gallons of water, chemicals and sand are transported to and from the well pads (46). Modeling studies in the Haynesville and Barnett Shales have suggested increased $\mathrm{NO}_{\mathrm{x}}$ and ozone levels in UOG regions $(82,83)$, whereas increases have been measured in active production areas in New Mexico and Wyoming $(84,85)$.

\section{Health effects associated with chemicals used in UOG operations}

\section{Semen quality}

Exposure to chemicals associated with UOG operations has been associated with reduced semen quality in men and laboratory animals. Specifically, exposure to BTEX chemicals has been associated with negative impacts on sperm quantity and quality. Exposure to rubber manufacturing workers has been associated with low sperm count, reduced sperm motility, abnormal sperm morphology, and abnormal semen viscosity (OR $>14,9$, 27 , and 4 respectively) (86). Workers exposed to toluene, xylene, and benzene showed reduced sperm vitality and activity (87). Toluene metabolites may have the ability to directly target the male reproductive organs by initiating oxidative stress mechanisms resulting in damage to the DNA in the testis (88). Chromosomal abnormalities in sperm have also been associated with benzene exposure $(89,90)$. Formaldehyde has been associated with decreased sperm count, motility, viability and morphology in mice (91). Ethylene glycol ethers have also been associated with lower sperm count in men $(92,93)$, an endpoint that may, in part, be due to reduced testosterone $(94,95)$. Ambient ozone has been negatively associated with sperm concentration in men (96) and in rats (97). Taken together, chemicals associated with UOG operations (e.g., benzene, toluene, formaldehyde, ethylene glycol and ozone) have been associated with negative impacts on semen quality, particularly reduced sperm counts. 


\section{Menstrual cycle and fecundity}

UOG chemicals have been associated with adverse effects on the menstrual cycle and overall fecundity in women. A study in the manufacturing industry suggests ethylene glycols might be a contributing factor to longer menstrual periods in women (98). Benzene and toluene exposure have been associated with abnormal menstrual cycle length in Beijing petrochemical workers (99).

Women exposed to toluene in the printing industry had lower fecundity (100). A two-fold overall reduction in fecundity was found in women working in areas of exposure to toluene in a cross-sectional time to pregnancy study (100). Toluene has been associated with difficulty conceiving, the inability to conceive, as well as premature menopause in women. Women exposed to toluene at work had more difficulty becoming pregnant than did their unexposed co-workers (9), and levels of benzene and toluene measured in breath have been associated with hormone profiles of nonconceptive menstrual cycles (101). In the laboratory, direct adverse effects of BTEX chemicals have been observed on ovarian cell apoptosis, proliferation, and hormone release in animal ovarian cells (102).

\section{Miscarriage and stillbirth}

The endocrine etiologies of miscarriage (spontaneous abortion) and stillbirths are not well understood, though they have been associated with exposure to environmental agents. Miscarriage and stillbirth are common disorders, occurring in $15 \%-20 \%$ of human pregnancies (103, 104). These can be caused by placental oxidative stress, degeneration, and a deterioration of placental function known as placental insufficiency (105), all leading to subsequent decreases in oxygen and nutrient transport to the fetus (106). Exposure to heavy metals during pregnancy is associated with increased risks of miscarriage and/or stillbirths. Heavy metals may be routinely mobilized during hydraulic fracturing operations and have been shown to contaminate surface and ground water $(7,35,107)$; in some cases (e.g., lead), they are also inadvertent contaminants in fracturing fluids (1).

Specifically, lead exposure is associated with an increased risk of miscarriage and stillbirth (108-112), potentially due to placental rupture (113). Exposure to cadmium has been shown to result in miscarriage and stillbirths in exposed mothers (114-116), potentially through decreased levels of antioxidants or enhanced lipid peroxidation resulting in oxidative stress $(115,116)$. Arsenic has also been associated with increased risk of miscarriage (117). Animal models have modeled transport of arsenic across the placenta and subsequent distribution and accumulation in the fetal liver and brain (118). Arsenic can cause placental insuffiency through multiple mechanisms like placental dysmorphogenesis (119), inhibition of enzymes and oxidative stress $(117,120)$ leading to inflammation $(121,122)$, and disruption of neovasculogenesis leading to aberrant placenta formation $(117,119)$. Further investigation is needed to evaluate the potential reproductive and developmental effects associated with exposure to heavy metals mobilized by UOG operations.

Meanwhile, exposure to benzene and toluene, commonly used and produced by UOG operations, have been associated with increased risks for miscarriage $(9,101)$. Women with high exposure to toluene had three to five times the miscarriage rate of those with low exposure (123), and women with occupational benzene exposure have been shown to have an increased rate of miscarriages based on retrospective recall (124). Paternal occupational exposure to toluene and formaldehyde has also been linked to miscarriage in their partners $(125,126)$.

Direct epidemiological associations between UOG development and miscarriage is lacking, though recent reports have raised concerns about potential effects. The first reported an unusually high rate of miscarriages and stillbirths from Glenwood Springs, Colorado in January 2014 (127). The majority of these cases presented from the Piceance Shale Basin, a densely-drilled UOG region in Western Colorado, though the Colorado Department of Public Health and Environment concluded that no single environmental factor could explain these anomalies (127). The second anecdotally reported an unusually high rate of miscarriages and stillbirths in Vernal, Utah. This region has seen active UOG development since 2005 and also receives substantial wastewater from other states, with recent work reporting elevated ozone concentrations in this area due to UOG activities (128). Researchers are currently investigating potential links between these adverse outcomes and the UOG processes that occur nearby.

\section{Preterm birth and low birth weight}

Exposure to chemicals associated with UOG operations is associated with increased risks of low birth weight (LBW) and preterm birth. LBW is defined as an infant birth weight of $<2.5 \mathrm{~kg}$ ( $5.5 \mathrm{lbs}$ ), and preterm birth is the birth of an infant prior to 37 weeks of pregnancy. Preterm birth occurs in $12 \%-13 \%$ of US pregnancies, and is a leading global cause of perinatal morbidity and mortality (129, 130). Intrauterine growth restriction (IUGR) refers to the 
poor growth of an infant in the womb, and is defined as a birth weight in the lowest $10 \%$ of normal weights for gestational age (131). Of the four million neonatal deaths that occur each year, at least $60 \%$ are due to LBW associated with IUGR and/or preterm birth (132). Several chemicals associated with UOG operations have been associated with negative birth outcomes. Mechanistically, LBW and preterm birth have been associated with reduced fetal estrogen or estrogen action. Smokers are more likely to have LBW babies (133), due, in part, to decreased estrogens from aromatase inhibitors in the smoke $(134,135)$. LBW has also been associated with exposure to anti-estrogenic polychlorinated biphenyls (PCBs) (136-139).

Particulate matter is one of the most common air pollutants to be linked to adverse birth outcomes. Fine particulate matter has been linked to preterm birth (140-142), IUGR and LBW $(11,143,144)$. Particulate matter (PM) is also commonly released into the surrounding air during tight oil and shale gas operations, especially where there are diesel emissions (66). A relationship between $\mathrm{NO}_{\mathrm{x}}$ and preterm birth has been observed (12), whereas exposure to $\mathrm{NO}_{\mathrm{x}}$ has been linked to reductions in birth weight $(145,146)$ and IUGR (147). Ozone, another byproduct of UOG operations, has also been linked in a number of studies to LBW and preterm birth $(140,144,148,149)$.

There is an association between air pollution and UOG operations and between air pollution and low birth weight, IUGR and preterm birth. Studies have now begun to assess a more direct link between UOG and adverse fetal outcomes. A preliminary study from the Marcellus Shale region reports increased LBW children from mothers living within $2.5 \mathrm{~km}$ of a natural gas well (150). By contrast, a recent work has reported a slight negative association between maternal residence proximity to natural gas wells and preterm birth and LBW (14). The findings from these and other studies indicate that exposure to chemicals from UOG operations (including BTEX, formaldehyde, and ethylene glycols) have the potential to adversely impact male and female fertility, as well as increase rates of miscarriage, preterm birth, and LBW.

\section{Birth defects and developmental origins of health and disease}

Maternal exposure to chemicals via inhalation or ingestion of contaminated air, water and foods can adversely affect developing fetuses $(151,152)$. Most chemicals pass from mother through the placenta to expose the developing embryo and fetus and many chemicals pass from breast milk to baby (152-154). This includes heavy metals, many persistent organic pollutants (POPs), and lipophilic chemicals including aromatic hydrocarbons like BTEX. POPs are characterized by their long half-lives and inability to be metabolized or excreted. These characteristics lead to bioaccumulation in the adipose tissue and result in a persistent "body burden" of hundreds of chemicals. Changes in absorption and metabolism during pregnancy and lactation can liberate chemicals from maternal fat and bone through fat mobilization and demineralization and expose the fetus and infant $(155,156)$.

McKenzie et al. examined maternal proximity to natural gas wells in rural Colorado and the incidence of three births defects recorded by the state of Colorado. Living within 10 miles of a natural gas well was associated with increased risk of congenital heart and neural tube defects (14). There is a clear potential mechanistic association between UOG chemicals and these birth defects because maternal exposure to chemicals used in UOG processes have been linked to specific birth defects. For example, maternal benzene exposure has been linked to neural tube defects in their children $(13,157)$. BTEX exposure during the first trimester of pregnancy is negatively associated with biparietal brain diameter between weeks 20 and 32 of pregnancy (158). Maternal EDC exposure has been linked to congenital heart defects, with increased risks for those with polymorphisms in multidrug resistance gene ABCB1 (159).

In addition to birth defects, fetuses and young children are uniquely sensitive to long-term adverse effects from chemical, environmental and nutritional exposures that may not always be apparent at birth. Alterations in the prenatal and postnatal environment can have long-term negative consequences, termed developmental origins of health and disease. Normal development is highly controlled by hormones, and disruption by manmade chemicals can permanently change the course of development. A sentinel example of developmental programming in humans is the use of diethystilbestrol (DES) by pregnant women in the attempt to prevent miscarriage. Later, it was found that maternal DES use increased the risk of reproductive tract abnormalities, vaginal and breast cancer, spontaneous abortion, and stillbirth in DES daughters whose mothers took DES during pregnancy $(160,161)$. DES sons also experienced long-term negative health impacts. These highlight the fact that some effects from developmental programming by EDCs may not become fully expressed until sexual maturity or even middle age.

The development of the human reproductive system begins during fetal life with sexual differentiation and the development of the reproductive organs. Many chemicals associated with UOG processes are EDCs that can block or antagonize hormone receptors, particularly androgen and 
estrogen receptors, termed antiestrogens and antiandrogens, respectively (19). Prenatal exposure to anti-androgenic EDCs like ethylene glycol can lead to delayed sexual development, hypospadias, cryptorchidism, decreased anogenital distance, which is associated with poor semen quality, and other problems (10, 162). Many pesticides have anti-androgenic activity, and a strong association has been found between pesticides and hypospadias (10, 25). Prenatal exposure to ethylene glycol-methyl cellosolve can lead to reproductive damage, congenital birth defects, intrauterine growth restriction and death (163). Perinatal exposure to toluene can reduce serum testosterone in preand post-pubertal rats (164). Prenatal exposure to antiestrogenic EDCs has been associated with reduced serum testosterone and elevated FSH in Taiwanese boys whose mothers had been exposed to polychlorinated biphenyls (PCBs) and dibenzofurans (PCDFs) during pregnancy (165). Abnormal menstruation and high FSH serum levels in adolescent girls have been associated with PCBs and PCDEs exposure during prenatal development [reviewed in (166)].

The reproductive tract is not the only target for EDCs during development. Perinatal exposure to EDCs has been shown to cause permanent changes in the brain, behavior, obesity, fertility, cancer and other adverse health outcomes in laboratory animals [reviewed in $(18,167,168)]$. These effects are dependent on the timing of exposure; these are also possibly inherited and passed through epigenetic changes that can be silent for years only to become apparent later (169). Further work should carefully assess the potential for exposure to UOG chemicals and developmental programming as the exposed populations age, particularly in regions like Texas and Colorado, that have experienced UOG production for the longest periods of time.

\section{Conclusions}

Exposure to chemical pollution can be linked to reproductive and developmental health impacts including infertility, miscarriage or spontaneous abortion, impaired fetal growth, and LBW. Given that many of the air and water pollutants found near UOG sites are recognized as being developmental and reproductive toxicants, there is a compelling need to increase our knowledge of the potential health consequences for infants, children, and adults from these chemicals through rapid and thorough further health research investigation. Chemicals used and produced in UOG operations are associated with human health effects and demonstrated to cause reproductive and developmental damage in laboratory animals. Whereas environmental human and animal monitoring is needed to measure actual exposure (170), we know enough to know the following:

- There has been and continues to be a dramatic expansion of UOG operations.

- Spills, leaks and discharges of UOG wastewater are common.

- UOG chemicals have been measured in air and water near operations.

- UOG chemicals have been directly linked with adverse reproductive and developmental health outcomes in laboratory studies.

- UOG chemicals have been associated with adverse human reproductive and developmental health outcomes in epidemiological studies.

Taken together, there is an urgent need for the following: 1) biomonitoring of human, domestic and wild animals for these chemicals; and 2) systematic and comprehensive epidemiological studies to examine the potential for human harm.

\section{Literature review}

The following peer-reviewed bibliographic databases were used: PubMed, Web of Science, and ScienceDirect, Physicians, Scientists and Engineers for Healthy Energy (PSE) citation database and NYU Erhman Medical Library.

Acknowledgments: Dr. Bushkin-Bedient is sincerely grateful to Erica DeNicola for her invaluable assistance. We also wish to thank Kara Klemp and Chiamaka Isiguzo for help with references. We also wish to thank the Center for Environmental Health (CEH), Concerned Health Professionals of New York and the Institute of Health and the Environment for their support and guidance.

Disclosure: The authors have no relevant financial relationships and no conflicts of interest.

\section{References}

1. Committee on Energy and Commerce, Chemicals Used in Hydraulic Fracturing, U.S.H.o. Representatives, Editor. 2011.

2. The Shale Gas Subcommittee of the Secretary of Energy Advisory Board, The SEAB Shale Gas Production Subcommittee Ninety-Day Report. 2011.

3. Riedl J, Rotter S, Faetsch S, Schmitt-Jansen M, Altenburger R. Proposal for applying a component-based mixture approach for 
ecotoxicological assessment of fracturing fluids. Environ Earth Sci 2013:1-14.

4. Maule AL, Makey CM, Benson EB, Burrows IJ, Scammell MK. Disclosure of hydraulic fracturing fluid chemical additives: analysis of regulations. New Solut 2013;23(1):167-87.

5. Warner NR, Jackson RB, Darrah T, Osborn SG, Down A, et al. Geochemical evidence for possible natural migration of Marcellus Formation brine to shallow aquifers in Pennsylvania. Proc Natl Acad Sci 2012;109(30):11961-6.

6. Orem W, Tatu C, Varonka M, Lerch H, Bates A, et al. Organic substances in produced and formation water from unconventional natural gas extraction in coal and shale. Int J Coal Geol 2014;126:20-31.

7. Fontenot BE, Hunt LR, Hildenbrand ZL, Carlton Jr DD, Oka H, et al. An evaluation of water quality in private drinking water wells near natural gas extraction sites in the barnett shale formation. Environ Sci Technol 2013;47:10032-40.

8. Colborn T, Kwiatkowski C, Schultz K, Bachran M. Natural gas operations from a public health perspective. Hum Ecol Risk Assess 2011;17(5):1039-56.

9. Attarchi MS, Ashouri M, Labbafinejad Y, Mohammadi S. Assessment of time to pregnancy and spontaneous abortion status following occupational exposure to organic solvents mixture. Int Arch Occup Environ Health 2012;85(3):295-303.

10. Christiansen S, Scholze M, Axelstad M, Boberg J, Kortenkamp A, et al. Combined exposure to anti-androgens causes markedly increased frequencies of hypospadias in the rat. Int J Androl 2008;31(2):241-8.

11. Dadvand P, Parker J, Bell ML, Bonzini M, Brauer M, et al. Maternal exposure to particulate air pollution and term birth weight: a multi-country evaluation of effect and heterogeneity. Environ Health Perspect 2013;121(3):267-373.

12. Llop S, Ballester F, Estarlich M, Esplugues A, Rebagliato M, et al. Preterm birth and exposure to air pollutants during pregnancy. Environ Res 2010;110(8):778-85.

13. Lupo PJ, Symanski E, Waller DK, Chan W, Langlois PH, et al. Maternal exposure to ambient levels of benzene and neural tube defects among offspring: Texas, 1999-2004. Environ Health Perspect 2011;119(3):397-402.

14. McKenzie LM, Guo R, Witter RZ, Savitz DA, Newman LS, et al. Birth outcomes and maternal residential proximity to natural gas development in rural Colorado. Environ Health Perspect 2014;122(4):412-7.

15. Bamberger M. Oswald RE. Impacts of gas drilling on human and animal health. New Solut 2012;22(1):51-77.

16. Zoeller RT, Brown TR, Doan LL, Gore AC, Skakkebaek NE, et al. Endocrine-disrupting chemicals and public health protection: a statement of principles from The Endocrine Society Endocrinology. 2012;153(9):4097-110.

17. Welshons WV, Thayer KA, Judy BM, Taylor JA, Curran EM, et al. Large effects from small exposures I: mechanisms for endocrine-disrupting chemicals with estrogenic activity. Environ Health Perspect 2003;111(8):994-1006.

18. Vandenberg LN, Colborn T, Hayes TB, Heindel JJ, Jacobs DR, et al. Hormones and endocrine-disrupting chemicals: lowdose effects and nonmonotonic dose responses. Endocr Rev. 2012;33(3):378-455.

19. Kassotis CD, Tillitt DE, Davis JW, Hormann AM, Nagel SC. Estrogen and androgen receptor activities of hydraulic fracturing chemicals and surface and ground water in a drilling-dense region. Endocrinology 2014;155(3):11.

20. Kassotis CD, Lin C-H, Tillitt D, Nagel SC. Endocrine disrupting activity of hydraulic fracturing chemicals and in vivo adverse health outcomes, in Impacts of Endocrine Disrupting Chemicals on Physiological Functions.MON-0365-MON-0365.

21. Thomas P, Budiantara L. Reproductive life history stages sensitive to oil and naphthalene in atlantic croaker. Marine Environ Res 1995;39:4.

22. Chang H-Y, Shih T-S, Guo YL, Tsai, C-Y, Hsu P-C. Sperm function in workers exposed to $\mathrm{N}, \mathrm{N}$-dimethylformamide in the synthetic leather industry. Fertil Steril 2004;81(6):1589-94.

23. Creasy D. A quantitative study of stage-specific spermatocyte damage following administration of ethylene glycol monomethyl ether in the rat. Exp Mol Pathol 1985;43(3):312-36.

24. Devillers J, Chezeau A, Thybaud E, Poulsen V, Porcher J-M, et al. Ecotoxicity of ethylene glycol monobutyl ether and its acetate. Toxicol Mech Method 2002;12:9.

25. Sohoni P, Sumpter JP. Several environmental oestrogens are also anti-androgens. J Endocrinol 1998;158:13.

26. Thayer KA, Belcher SM. Mechanisms of action of bisphenol a and other biochemical/molecular interactions. World Health Organization, 2011.

27. Miao M, Yuan W, Zhu G, He X, Li DK. In utero exposure to bisphenol-A and its effect on birth weight of offspring. Reprod Toxicol 2011;32(1):64-8.

28. Maffini MV, Rubin BS, Sonnenschein C, Soto AM. Endocrine disruptors and reproductive health: the case of bisphenol-A. Mol Cell Endocrinol 2006;254-255:179-86.

29. Pflieger-Bruss S, Schuppe HC, Schill WB. The male reproductive system and its susceptibility to endocrine disrupting chemicals. Andrologia 2004;36(6):337-45.

30. Jacobson-Dickman E, Lee MM. The influence of endocrine disruptors on pubertal timing. Curr Opin Endocrinol Diabetes Obes 2009;16(1):25-30.

31. Eertmans F, Dhooge W, Stuyvaert S, Comhaire F. Endocrine disruptors: effects on male fertility and screening tools for their assessment. Toxicol In Vitro 2003;17(5-6):515-24.

32. Vidic RD, Brantley SL, Vandenbossche JM, Yoxtheimer D, Abad JD. Impact of shale gas development on regional water quality. Science 2013;340(6134):1235009.

33. Ellsworth WL. Injection-induced earthquakes. Science 2013;341(6142):1225942.

34. Holland A. Earthquakes triggered by hydraulic fracturing in South-Central Oklahoma. B Seismol Soc Am 2013;103(3): 1784-92.

35. Alley B, Beebe A, Rodgers Jr J, Castle JW. Chemical and physical characterization of produced waters from conventional and unconventional fossil fuel resources. Chemosphere 2011;85(1):74-82.

36. Zhang T, Gregory K, Hammack RW, Vidic RD. Co-precipitation of radium with barium and strontium sulfate and its impact on the fate of radium during treatment of produced water from unconventional gas extraction. Environ Sci Technol 2014;48(8):4596-603.

37. Masoner JR, Kolpin DW, Furlong ET, Cozzarelli IM, Gray JL, et al. Contaminants of emerging concern in fresh leachate from landfills in the conterminous United States. Environ Sci Process Impacts 2014;16(10):2335-54. 
38. Rozell DJ, Reaven SJ. Water pollution risk associated with natural gas extraction from the Marcellus shale. Risk Anal 2012;32(8):1382-93.

39. McKenzie LM, Witter RZ, Newman LS, Adgate JL. Human health risk assessment of air emissions from development of unconventional natural gas resources. Sci Total Environ 2012;424(1):9.

40. DiGiulio DC, Wilkin RT, Miller C, Oberley G. Investigation of ground water contamination near Pavillion. Wyoming, Ada, OK: US Environmental Protection Agency, Office of Research and Development. Report nr EPA 600/R-00/000.

41. Kell S. State oil and gas agency groundwater investigations and their role in advancing regulatory reforms. In: Groundwater Protection Council, editor. A two-state review. Ohio and Texas: Groundwater Protection Council, 2011:165. Available at: http:// fracfocus.org/sites/default/files/publications/state_oil_gas_ agency_groundwater_investigations_optimized.pdf.

42. Osborn SG, Vengosh A, Warner NR, Jackson RB. Methane contamination of drinking water accompanying gas-well drilling and hydraulic fracturing. Proc Natl Acad Sci USA 2011;108(20):5.

43. Jackson RB, Vengosh A, Darrah TH, Warner NR, Down A, et al. Increased stray gas abundance in a subset of drinking water wells near Marcellus shale gas extraction. Proc Natl Acad Sci USA 2013;110(28):11250-5.

44. Brantley SL, Yoxtheimer D, Arjmand S, Grieve P, Vidic R, et al. Water resource impacts during unconventional shale gas development: The Pennsylvania experience. Int J Coal Geol 2014;126(1):140-56.

45. Gross SA, Avens HJ, Banducci AM, Sahmel J, Panko JM, et al. Analysis of BTEX groundwater concentrations from surface spills associated with hydraulic fracturing operations. J Air Waste Manag Assoc 2013;63(4):424-32.

46. Vengosh A, Jackson RB, Warner N, Darrah TH, Kondash A. A critical review of the risks to water resources from unconventional shale gas development and hydraulic fracturing in the United States. Environ Sci Technol 2014;48(15):8334-48.

47. Ferrar KJ, Michanowicz DR, Christen CL, Mulcahy N, Malone SL, et al. Assessment of effluent contaminants from three facilities discharging Marcellus Shale wastewater to surface waters in Pennsylvania. Environ Sci Technol 2013;47(7):3472-81.

48. Korfmacher KS, Jones WA, Malone SL, Vinci LF. Public health and high volume hydraulic fracturing. New Solut 2013;23(1):13-31.

49. Mauter MS, Alvarez PJ, Burton A, Cafaro DC, Chen W, et al. Regional variation in water-related impacts of shale gas development and implications for emerging international plays. Environ Sci Technol 2014;48(15):8298-306.

50. Ingraffea AR, Wells MT, Santoro RL, Shonkoff SB. Assessment and risk analysis of casing and cement impairment in oil and gas wells in Pennsylvania, 2000-2012. Proc Natl Acad Sci USA 2014;111(30):10955-60.

51. Colorado Oil \& Gas Conservation Commission, Colorado Oil and Gas Information System (COGIS). 2014. Available at: http://cogcc. state.co.us/.

52. Colorado Oil \& Gas Conservation Commission. Conservation Commission Colorado Weekly and Monthly Oil \& Gas Statistics. 2012. (cited 2012 May 15, 2012); 5/7/12: Available at: http:// www.colorado.gov/cogcc.

53. Ziemkiewicz PF, Quaranta JD, Darnell A, Wise R. Exposure pathways related to shale gas development and procedures for reducing environmental and public risk. J Nat Gas Sci Eng 2014;16:8
54. Li H, Carlson KH. Distribution and origin of groundwater methane in the wattenberg oil and gas field of Northern Colorado. Environ Sci Technol 2014;48(3):1484-91.

55. Darrah TH, Vengosh A, Jackson RB, Warner NR, Poreda RJ. Noble gases identify the mechanisms of fugitive gas contamination in drinking-water wells overlying the Marcellus and Barnett Shales. Proc Natl Acad Sci USA 2014; 111(39):14076-81.

56. Gilmore KR, Hupp RL, Glathar J. Transport of hydraulic fracturing water and wastes in the Susquehanna River Basin, Pennsylvania. J Environ Eng 2014;140(5):10.

57. Burton Jr GA, Basu N, Ellis BR, Kapo KE, Entrekin S, et al. Hydraulic "fracking": are surface water impacts an ecological concern? Environ Toxicol Chem 2014;33(8):1679-89.

58. Braga 0, Smythe GA, Schafer Al, Feitz AJ. Steroid estrogens in primary and tertiary wastewater treatment plants. Water Sci Technol 2005;52(8):273-8.

59. Westerhoff P, Yoon Y, Snyder S, Wert E. Fate of endocrinedisruptor, pharmaceutical, and personal care product chemicals during simulated drinking water treatment processes. Environ Sci Technol 2005;39:15.

60. Campbell C, Borglin S, Green F, Grayson A, Wozei E, et al. Biologically directed environmental monitoring, fate, and transport of estrogenic endocrine disrupting compounds in water: a review. Chemosphere 2006;65(8):1265-80.

61. US Environmental Protection Agency Office of Water, Drinking Water and Ground Water Statistics for 2008, in Report nr EPA 816-K-08-004. 2008: Available at: http://www.epa.gov/ogwdw/ databases/pdfs/data_factoids_2008.pdf.

62. Roy AA, Adams PJ, Robinson AL. Air pollutant emissions from the development, production, and processing of Marcellus Shale natural gas. J Air Waste Manag Assoc 2014;64(1):20.

63. Colborn T, Schultz K, Herrick L, Kwiatkowski C. An exploratory study of air quality near natural gas operations. Hum Ecol Risk Assess 2014;20(1):20.

64. Pétron G, Frost G, Miller BR, Hirsch Al, Montzka SA, et al. Hydrocarbon emissions characterization in the Colorado Front Range: a pilot study. J Geophys Res 2012;117:19.

65. Steinzor N, Subra W, Sumi L. Investigating links between shale gas development and health impacts through a community survey project in Pennsylvania. New Solut 2013;23(1):29.

66. Moore CW, Zielinska B, Petron G, Jackson RB. Air impacts of increased natural gas acquisition, processing and use: a critical review. Environ Sci Technol 2014;48(15):8349-59. Available at: http://sites.biology.duke.edu/jackson/est2014a.pdf.

67. Brown D, Weinberger B, Lewis C, Bonaparte H. Understanding exposure from natural gas drilling puts current air standards to the test. Rev Environ Health 2014;29:277-92.

68. Helmig D, Thompson C, Evans J, Park JH. Highly elevated atmospheric levels of volatile organic compounds in the Uintah Basin, Utah. Environ Sci Technol 2014;48(9):4707-15.

69. Sommariva R, Blake RS, Cuss RJ, Cordell RL, Harrington JF, et al. Observations of the release of non-methane hydrocarbons from fractured shale. Environ Sci Technol 2014;48(15):8891-6.

70. Miller SM, Wofsy SC, Michalak AM, Kort EA, Andrews AE, et al. Anthropogenic emissions of methane in the United States. Proc Natl Acad Sci USA 2013;110(50):20018-22.

71. Howarth RW, Santoro R, Ingraffea A. Methane and the greenhouse-gas footprint of natural gas from shale formations. Climatic Change 2011;106:12. 
72. Allen DT, Torres VM, Thomas J, Sullivan DW, Harrison M, et al. Measurements of methane emissions at natural gas production sites in the United States. Proc Natl Acad Sci USA 2013;110(44):17768-73.

73. Howarth RW. A bridge to nowhere: methane emissions and the greenhouse gas footprint of natural gas. Energy Sci Eng 2014;1:14.

74. Karion A, Sweeney C, Petron G, Frost G, Hardesty RM, et al. Methane emissions estimate from airborne measurements over a western United States natural gas field. Geophys Res Lett 2013;40:1-5.

75. Jackson RB, Down A, Phillips NG, Ackley RC, Cook CW, et al. Natural gas pipeline leaks across Washington, DC. Environ Sci Technol 2014;48(3):2051-8.

76. Gilman JB, Lerner BM, Kuster WC, de Gouw JA. Source signature of volatile organic compounds from oil and natural gas operations in northeastern Colorado. Environ Sci Technol 2013;47(3):1297-305.

77. Bar-Ilan A, Friesen R, Grant J, Pollack A, Henderer D, et al. Development of Baseline 2006 Emissions from Oil and Gas Activity in Denver-Julesberg Basin. Prepared for the Western Governors' Association by ENVIRON International Corp Novato, CA, 2008,. Available at: http://www.epa.gov/ttnchie1/conference/ei17/ session2/amnon.pdf.

78. Colborn T, Schultz K, Herrick L, Kwiatkowski C. An exploratory study of air quality near natural gas operations. Hum Ecol Risk Assess 2013;20(1):86-105.

79. Zhang H, Li J, Ying Q, Guven B, Olaguer E. Source apportionment of Formaldehyde during Texas AQS 2006 using a source-oriented chemical transport model. J GeophysRes Atmos 2006;118(3):1525-35.

80. Macey GP, Breech R, Chernaik M, Cox C, Larson D, et al. Air concentrations of volatile compounds near oil and gas production: a community-based exploratory study. Environ Health 2014;13:82.

81. Pleijel H, Danielsson H, Karlsson GP, Gelang J, Karlsson PE, et al. An ozone flux-response relationship for wheat. Environ Pollut 2000;109(3):453-62.

82. Kemball-Cook S, Bar-Ilan A, Grant J, Parker L, Jung J, et al. Ozone impacts of natural gas development in the Haynesville Shale. Environ Sci Technol 2010;44(24):9357-63.

83. Olaguer EP. The potential near-source ozone impacts of upstream oil and gas industry emissions. J Air Waste Manag Assoc 2012;62(8):966-77.

84. Rodriguez MA, Barna MG, Moore T. Regional impacts of oil and gas development on ozone formation in the western United States. J Air Waste Manag Assoc 2009;59(9):1111-8.

85. Schnell RC, Oltmans SJ, Neely RR, Endres MS, Molenar JV, et al. Rapid photochemical production of ozone at high concentrations in a rural site during winter. Nat Geosci 2009;2:120-2.

86. De Celis R, Feria-Velasco A, Gonzalez-Unzaga M, Torres-Calleja J, Pedron-Nuevo N. Semen quality of workers occupationally exposed to hydrocarbons. Fertil Steril 2000;73(2):221-8.

87. Xiao G, Pan C, Cai Y, Lin H, Fu Z. Effect of benzene, toluene, xylene on the semen quality and the function of accessory gonad of exposed workers. Ind Health 2001;39(2):206-10.

88. Nakai N, Murata M, Nagahama M, Hirase T, Tanaka M, et al. Oxidative DNA damage induced by toluene is involved in its male reproductive toxicity. Free Radic Res 2003;37(1):69-76.
89. Xing C, Marchetti F, Li G, Weldon RH, Kurtovich E, et al. Benzene exposure near the U.S. permissible limit is associated with sperm aneuploidy. Environ Health Perspect 2010;118(6):833-9.

90. Marchetti F, Eskenazi B, Weldon RH, Li G, Zhang L, et al. Occupational exposure to benzene and chromosomal structural aberrations in the sperm of Chinese men. Environ Health Perspect 2012;120(2):229-34.

91. Vosoughi S, Khavanin A, Salehnia M, Asilian Mahabadi H, Shahverdi A, et al. Adverse effects of formaldehyde vapor on mouse sperm parameters and testicular tissue. Int J Fertil Steril 2013;6(4):250-67.

92. Veulemans H, Steeno O, Masschelein R, Groeseneken D. Exposure to ethylene glycol ethers and spermatogenic disorders in man: a case-control study. Br J Ind Med 1993;50(1):71-8.

93. Welch LS, Schrader SM, Turner TW, Cullen MR. Effects of exposure to ethylene glycol ethers on shipyard painters: II. Male reproduction. Am J Ind Med 1988;14(5):509-26.

94. Svensson BG, Nise G, Erfurth EM, Nilsson A, Skerfving S. Hormone status in occupational toluene exposure. Am J Ind Med 1992;22(1):99-107.

95. Svensson BG, Nise G, Erfurth EM, Olsson H. Neuroendocrine effects in printing workers exposed to toluene. $\mathrm{Br} J$ Ind Med 1992;49(6):402-8.

96. Bonde JP. Ozone and semen quality. Environ Health Perspect 2007;115(4):A185; author reply A185-6.

97. Jedlinska-Krakowska M, Gizejewski Z, Dietrich GJ, Jakubowski K, Glogowski J, et al. The effect of increased ozone concentrations in the air on selected aspects of rat reproduction. Pol J Vet Sci 2006;9(1):11-6.

98. Hsieh GY, Wang JD, Cheng TJ, Chen PC. Prolonged menstrual cycles in female workers exposed to ethylene glycol ethers in the semiconductor manufacturing industry. Occup Environ Med 2005;62(8):510-6.

99. Ekpenyong CE, Davies K, Daniel N. Effects of gasoline inhalation on menstrual characteristics and the hormonal profile of female petrol pump workers. J Environ Prot 2013;4:65-73.

100. Plenge-Bonig A, Karmaus W. Exposure to toluene in the printing industry is associated with subfecundity in women but not in men. Occup Environ Med 1999;56(7):443-8.

101. Reutman SR, LeMasters GK, Knecht EA, Shukla R, Lockey JE, et al. Evidence of reproductive endocrine effects in women with occupational fuel and solvent exposures. Environ Health Perspect 2002;110(8):805-11.

102. Sirotkin AV, Kádasi A, Baláži A, Baková Z, Harrath AH, et al. Influence of petrochemical industry environmental contaminants on animal ovarian cells. J Microb Biotech Food Sci 2012;2(2):517-25.

103. Jauniaux E, Poston L, Burton GJ. Placental-related diseases of pregnancy: Involvement of oxidative stress and implications in human evolution. Hum Reprod Update 2006;12(6):747-55.

104. Reddy UM, Laughon SK, Sun L, Troendle J, Willinger M, et al. Prepregnancy risk factors for antepartum stillbirth in the United States. Obstet Gynecol 2010;116(5):1119-26.

105. Gagnon R. Placental insufficiency and its consequences. Eur J Obstet Gynecol Reprod Biol 2003;110(Suppl 1):S99-107.

106. Baschat AA. Fetal responses to placental insufficiency: an update. Br J Obstet Gynecol 2004;111(10):1031-41.

107. Stringfellow WT, Domen JK, Camarillo MK, Sandelin WL, Borglin S. Physical, chemical, and biological characteristics of compounds used in hydraulic fracturing. J Hazard Mater 2014;275:37-54. 
108. Baghurst PA, Robertson EF, Oldfield RK, King BM, McMichael AJ, et al. Lead in the placenta, membranes, and umbilical cord in relation to pregnancy outcome in a lead-smelter community. Environ Health Perspect 1991;90:315-20.

109. Bellinger DC. Teratogen update: lead and pregnancy. Birth Defects Res A Clin Mol Teratol 2005;73(6):409-20.

110. Chalupka S, Chalupka AN. The impact of environmental and occupational exposures on reproductive health. J Obstet Gynecol Neonatal Nurs 2010;39(1):84-100; quiz 100-2.

111. Gundacker C, Frohlich S, Graf-Rohrmeister K, Eibenberger B, Jessenig V, et al. Perinatal lead and mercury exposure in Austria. Sci Total Environ 2010;408(23):5744-9.

112. Flora S, Pachauri V, Saxena G. Arsenic, cadmium and lead. Reproductive and developmental toxicology. London: Academic Press, 2011:416-38.

113. Fahim MS, Fahim Z, Hall DG. Effects of subtoxic lead levels on pregnant women in the state of Missouri. Res Commun Chem Pathol Pharmacol 1976;13(2):309-31.

114. Godt J, Scheidig F, Grosse-Siestrup C, Esche V, Brandenburg P, et al. The toxicity of cadmium and resulting hazards for human health. J Occup Med Toxicol 2006;1:22.

115. Saad AA, Hegazy NM, Amer N, Gaber K, Youssef Al, et al. The role of cadmium exposure on spontaneous abortion. World J Med Sci 2012;7(4):6.

116. Thompson J, Bannigan J. Cadmium: toxic effects on the reproductive system and the embryo. Reprod Toxicol 2008;25(3):304-15.

117. Vahter M. Effects of arsenic on maternal and fetal health. Annu Rev Nutr 2009;29:381-99.

118. Jin Y, Xi S, Li X, Lu C, Li G, et al. Arsenic speciation transported through the placenta from mother mice to their newborn pups. Environ Res 2006;101(3):349-55.

119. He W, Greenwell RJ, Brooks DM, Calderon-Garciduenas L, Beall $H D$, et al. Arsenic exposure in pregnant mice disrupts placental vasculogenesis and causes spontaneous abortion. Toxicol Sci 2007;99(1):244-53.

120. Kumagai Y, Sumi D. Arsenic: signal transduction, transcription factor, and biotransformation involved in cellular response and toxicity. Annu Rev Pharmacol Toxicol 2007;47:243-62.

121. van den Hooven EH, de Kluizenaar Y, Pierik FH, Hofman A, van Ratingen SW, et al. Chronic air pollution exposure during pregnancy and maternal and fetal C-reactive protein levels: the Generation R Study. Environ Health Perspect 2012;120(5):746-51.

122. Fry RC, Navasumrit P, Valiathan C, Svensson JP, Hogan BJ, et al. Activation of inflammation/NF-kappaB signaling in infants born to arsenic-exposed mothers. PLoS Genet 2007;3(11):e207.

123. Bukowski JA. Review of the epidemiological evidence relating toluene to reproductive outcomes. Regul Toxicol Pharmacol 2001;33(2):147-56.

124. Xu X, Cho SI, Sammel M, You L, Cui S, et al. Association of petrochemical exposure with spontaneous abortion. Occup Environ Med 1998;55(1):31-6.

125. Taskinen H, Anttila A, Lindbohm ML, Sallmen M, Hemminki K. Spontaneous abortions and congenital malformations among the wives of men occupationally exposed to organic solvents. Scand J Work Environ Health 1989;15(5):345-52.

126. Wang HX, Zhou DX, Zheng LR, Zhang J, Huo YW, et al. Effects of paternal occupation exposure to formaldehyde on reproductive outcomes. J Occup Environ Med 2012;54(5):518-24.

127. Colorado Department of Public Health and Environment. Glenwood Springs Prenatal Report, April 2014. State of Colo- rado, 2014. Available at: http://www.colorado.gov/cs/Satellit e?blobcol=urldata\&blobheadername1=Content-Disposition \& blobheadername2=Content-Type\&blobheadervalue1=inline;+file name\%3D\%22Glenwood+Springs+Prenatal+Report.pdf \%22\&blo bheadervalue2=application/pdf\&blobkey=id\&blobtable=Mungo Blobs\&blobwhere $=1251979207926 \&$ ssbinary $=$ true.

128. Edwards PM, Brown SS, Roberts JM, Ahmadov R, Banta RM, et al. High winter ozone pollution from carbonyl photolysis in an oil and gas basin. Nature 2014;514(7522):351-4.

129. Simmons LE, Rubens CE, Darmstadt GL, Gravett MG. Preventing preterm birth and neonatal mortality: exploring the epidemiology, causes, and interventions. Semin Perinatol 2010;34(6): 408-15.

130. Goldenberg RL, Culhane JF, lams JD, Romero R. Epidemiology and causes of preterm birth. Lancet 2008;371(9606):75-84.

131. Agarwal A, Aponte-Mellado A, Premkumar BJ, Shaman A, Gupta $S$. The effects of oxidative stress on female reproduction: a review. Reprod Biol Endocrinol 2012;10:49.

132. Lawn JE, Cousens S, Zupan J. Lancet Neonatal Survival Steering T. 4 million neonatal deaths: when? where? why? Lancet 2005;365(9462):891-900.

133. Petridou E, Panagiotopoulou K, Katsouyanni K, Spanos E, Trichopoulos D. Tobacco smoking, pregnancy estrogens, and birth weight. Epidemiol 1990;1(3):247-50.

134. Kitawaki J, Inoue S, Tamura T, Yamamoto T, Honjo H, et al. Cigarette smoking during pregnancy lowers aromatase cytochrome P-450 in the human placenta. J Steroid Biochem Mol Biol 1993;45(6):485-91.

135. Osawa Y, Tochigi B, Tochigi M, Ohnishi S, Watanabe Y, et al. Aromatase inhibitors in cigarette smoke, tobacco leaves and other plants. J Enzyme Inhib 1990;4(2):187-200.

136. Baibergenova A, Kudyakov R, Zdeb M, Carpenter DO. Low birth weight and residential proximity to $\mathrm{PCB}$-contaminated waste sites. Environ Health Perspect 2003;111(10):1352-7.

137. Rylander L, Stromberg U, Dyremark E, Ostman C, Nilsson-Ehle $\mathrm{P}$, et al. Polychlorinated biphenyls in blood plasma among Swedish female fish consumers in relation to low birth weight. Am J Epidemiol 1998;147(5):10.

138. Calo M, Alberghina D, Bitto A, Lauriano ER, Lo Cascio P. Estrogenic followed by anti-estrogenic effects of PCBs exposure in juvenil fish (Spaurus aurata). Food Chem Toxicol 2010; 48(8-9):2458-63.

139. Connor K, Ramamoorthy K, Moore M, Mustain M, Chen I, et al. Hydroxylated polychlorinated biphenyls (PCBs) as estrogens and antiestrogens: structure-activity relationships. Toxicol Appl Pharmacol 1997;145(1):111-23.

140. Hansen C, Neller A, Williams G, Simpson R. Maternal exposure to low levels of ambient air pollution and preterm birth in Brisbane, Australia. Br J Obstet Gynecol 2006;113(8):935-41.

141. Huynh M, Woodruff TJ, Parker JD, Schoendorf KC. Relationships between air pollution and preterm birth in California. Paediatr Perinat Epidemiol 2006;20(6):454-61.

142. Suh YJ, Kim H, Seo JH, Park H, Kim YJ, et al. Different effects of PM10 exposure on preterm birth by gestational period estimated from time-dependent survival analyses. Int Arch Occup Environ Health 2009;82(5):613-21.

143. Fleischer NL, Merialdi M, van Donkelaar A, Vadillo-Ortega F, Martin RV, et al. Outdoor air pollution, preterm birth, and low birth weight: analysis of the world health organization global 
survey on maternal and perinatal health. Environ Health Perspect 2014;122(4):425-30.

144. Morello-Frosch R, Jesdale BM, Sadd JL, Pastor M. Ambient air pollution exposure and full-term birth weight in California. Environ Health 2010;9:44.

145. Darrow LA, Klein M, Strickland MJ, Mulholland JA, Tolbert PE. Ambient air pollution and birth weight in full-term infants in Atlanta, 1994-2004. Environ Health Perspect 2011;119(5): 731-7.

146. Savitz DA, Bobb JF, Carr JL, Clougherty JE, Dominici F, et al. Ambient fine particulate matter, nitrogen dioxide, and term birth weight in New York, New York. Am J Epidemiol 2014;179(4):457-66.

147. Liu S, Krewski D, Shi Y, Chen Y, Burnett RT. Association between gaseous ambient air pollutants and adverse pregnancy outcomes in Vancouver, Canada. Environ Health Perspect 2003;111(14):1773-8.

148. Olsson D, Mogren I, Forsberg B. Air pollution exposure in early pregnancy and adverse pregnancy outcomes: a register-based cohort study. Br Med J Open 2013;3(2):1-8.

149. Salam MT, Millstein J, Li YF, Lurmann FW, Margolis HG, et al. Birth outcomes and prenatal exposure to ozone, carbon monoxide, and particulate matter: results from the Children's Health Study. Environ Health Perspect 2005;113(11):1638-44.

150. Hill EL. Shale gas development and infant health: evidence from Pennsylvania. Working Paper, 2013, Revision December 2013.

151. Barr DB, Bishop A, Needham LL. Concentrations of xenobiotic chemicals in the maternal-fetal unit. Reprod Toxicol 2007;23(3):260-6.

152. Needham LL, Grandjean P, Heinzow B, Jorgensen PJ, Nielsen $F$, et al. Partition of environmental chemicals between maternal and fetal blood and tissues. Environ Sci Technol 2011;45(3):1121-6.

153. Landrigan PJ, Sonawane B, Mattison D, McCally M, Garg A. Chemical contaminants in breast milk and their impacts on children's health: an overview. Environ Health Perspect 2002;110(6):A313-5.

154. Sonawane BR. Chemical contaminants in human milk: an overview. Environ Health Perspect 1995;103(5):197-205.

155. Colborn T, vom Saal FS, Soto AM. Developmental effects of endocrine-disrupting chemicals in wildlife and humans. Environ Health Perspect 1993;101(5):378-84.

156. Hackley B, Feinstein A, Dixon J. Air pollution: impact on maternal and perinatal health. J Midwifery Womens Health 2007;52(5):435-43.

157. Ruckart PZ, Bove FJ, Maslia M. Evaluation of exposure to contaminated drinking water and specific birth defects and childhood cancers at Marine Corps Base Camp Lejeune, North Carolina: a case-control study. Environ Health 2013;12:104.
158. Aguilera I, Garcia-Esteban R, Iniguez C, Nieuwenhuijsen MJ, Rodriguez A, et al. Prenatal exposure to traffic-related air pollution and ultrasound measures of fetal growth in the INMA Sabadell cohort. Environ Health Perspect 2010;118(5):705-11.

159. Wang C, Xie L, Zhou K, Zhan Y, Li Y, et al. Increased risk for congenital heart defects in children carrying the $A B C B 1$ Gene C3435T polymorphism and maternal periconceptional toxicants exposure. PLoS One 2013;8(7):e68807.

160. Herbst AL, Hubby MM, Blough RR, Azizi F. A comparison of pregnancy experience in DES-exposed and DES-unexposed daughters. J Reprod Med 1980;24(2):62-9.

161. Hoover RN, Hyer M, Pfeiffer RM, Adam E, Bond B, et al. Adverse health outcomes in women exposed in utero to diethylstilbestrol. N Engl J Med 2011;365(14):1304-14.

162. Mendiola J, Stahlhut RW, Jorgensen N, Liu F, Swan SH. Shorter anogenital distance predicts poorer semen quality in young men in Rochester, New York. Environ Health Perspect 2011;119(7):958-63.

163. Arteaga-Martínez M, García-Peláez I, Aguirre-Luna O, Saavedra-Ontiveros D. Teratogenic effect of ethylene glycol-methyl cellosolve mixture in rats: i. reproductive damage. Int J Morphol 2010;28(4):1173-80.

164. Hansson T, Pettersson BM, Eneroth P, Gustafsson JA. Neonatal exposure to toluene: effects on the development of liver microsomal cytochrome P-450 and serum hormone levels in the rat. Toxicology 1985;37(1-2):39-50.

165. Hsu JF, Guo YL, Yang SY, Liao PC. Congener profiles of PCBs and PCDD/Fs in Yucheng victims fifteen years after exposure to toxic rice-bran oils and their implications for epidemiologic studies. Chemosphere 2005;61(9):1231-43.

166. Leijs MM, van der Linden LM, Koppe JG, Olie K, van Aalderen WM, et al. The influence of perinatal and current dioxin and PCB exposure on reproductive parameters (sex-ratio, menstrual cycle characteristics, endometriosis, semen quality, and prematurity): a review. Biomonitoring 2014;1(1):1-15.

167. Diamanti-Kandarakis E, Bourguignon JP, Giudice LC, Hauser R, Prins GS, et al. Endocrine-disrupting chemicals: an Endocrine Society scientific statement. Endocr Rev 2009;30(4):293-342.

168. Vandenberg LN. Low-dose effects of hormones and endocrine disruptors. Vitam Horm 2014;94:129-65.

169. Zama AM, Uzumcu M. Epigenetic effects of endocrine-disrupting chemicals on female reproduction: an ovarian perspective. Front Neuroendocrinol 2010;31(4):420-39.

170. Penning TM, Breysse PN, Gray K, Howarth M, Yan B. Environmental health research recommendations from the interenvironmental health sciences core center working group on unconventional natural gas drilling operations. Environ Health Perspect 2014;122(11):1155-9. 